\title{
Development and Cost Economics of Bhujia Incorporated with Spent Hen Meat Powder
}

\author{
B.K. Sarkar*, S. Upadhyay, P. Gogoi, A. Das and M. Hazarika \\ AICRP on PHET, Department of Livestock Products Technology, \\ College of Veterinary Science, AAU, Khanapara, Guwahati-781022, India \\ *Corresponding author
}

\begin{tabular}{|l|}
\hline Ke y w or d s \\
Bhujia, Spent hen \\
meat powder, Cost \\
economics, MRP, \\
Cost benefit ratio \\
\hline Article Info \\
\hline $\begin{array}{l}\text { Accepted: } \\
\text { 10 January } 2019 \\
\text { Available Online: } \\
\text { 10 February } 2019\end{array}$ \\
\hline \hline
\end{tabular}

\section{Introduction}

Poultry industry has emerged as an organized, scientific and one of the fastest growing sector of livestock economy. Total poultry population in India is estimated to be 729.21 million which accounts for nearly $45 \%$ of the total production of meat (BAHS, 2014). India ranks fifth in chicken meat and third in egg in the world with production figures of 2.19 MT of chicken meat and 63 billion eggs (DAHD \& F, 2012). Due to cost competitiveness, nutritional quality, universal availability and absence of religious taboos, chicken meat occupies an important component of nonvegetarian diet in India.

Poultry industry in India is comprised of 24 crores of layers (Kotaiah, 2018) with annual population growth rate of $8 \%$ (Desikan and 
Megarajan, 2014). Spent hen meat is a byproduct of egg industry obtained from old and culled chicken, after productive and reproductive phase of life; which has high fat and cholesterol content, low tenderness, less juiciness and poor functional characteristics resulting in low acceptability and lower remunerative prices as compared to broiler meat (Saini, 2016). Development of value added meat products from spent hen meat has better prospect in view of their lower cost and suitability for processing (Kondaiah and Panda, 1992). Utilization of nutritious, easily available and economically viable spent hen meat in traditional snack formulation can overcome the problem of improper utilization of spent hens and will also improve nutritional value of the snacks.

In India Bhujia is one of the popular snacks taken at tea time in average households. Bhujia is gram flour based, deep fried, shelf stable, ready to eat salted snack and incorporation of meat powder in its formulation will not only upgrade the nutritional value but will also improve the taste and flavour of the product. It is prepared by deep fat frying process and thus can be stored at ambient temperature for longer period. Young generation is highly cherished by non vegetarian snacks due to its convenient nature and overwhelming taste and flavor. Diversity of convenience/ready-tocook/ready-to-serve chicken meat products such as kababs, tikkas, lollipops, fingers, nuggets, patties and sausages exist in the markets. However, perishability of meat products has been regarded as a very serious problem, particularly in tropical countries like India, where household refrigeration facility is scanty (Kumar et al., 2015). In the present era, development of safe and shelf stable products is the priority of food industry to curtail the high energy cost involved in food preservation and for consumer safety. Also high fat containing meat products is having the problem of off odor and oxidation which can be overcome by the addition of natural antioxidants in the form of spices and condiments. Natural antioxidants extracted from herbs and spices exhibit various degree of efficiency when used in different food application (Bowser et al., 2014). Bhujia being a shelf stable product can be formulated with spent hen meat powder incorporating different spices and ingredients to improve its nutritional properties, shelf stability and to increase its popularity.

Thus, the present study was undertaken to develop and literal economization of preparation cost of bhujia incorporated with spent hen meat powder.

\section{Materials and Methods}

Spent hens of commercial breed were obtained from Regional Poultry Breeding Farm, Kyrdemkulai, Ri Bhoi District, Meghalaya, India. Following ante-mortem examination, spent hens were slaughtered, dressed and deboned manually maintaining hygienic conditions in the laboratory of AICRP on PHET, Department of LPT, C. V. Sc., AAU, Khanapara, Assam, India. Postmortem examination of the spent hens was also performed to detect any kind of abnormalities. All separable fat, fascia and connective tissue were trimmed off and meat was minced twice through $6 \mathrm{~mm}$ sieve in a meat mincer, packed in low density polyethylene (150 $\mu \mathrm{m}$ thickness) bags, and frozen at $-18 \pm 2{ }^{\circ} \mathrm{C}$ till further use. Refined salt (Tata Chemicals Ltd., Mumbai), refined oil, gram flour, potato starch powder, rice flour, chat mashala, hing (asafoetida) etc. procured from local market of Guwahati. Red chilli powder, black pepper powder, garlic powder and cardamom powder was prepared in the laboratory. Spent hen meat powder was prepared as depicted in figure 1 . 
Four combinations of bhujia (Table 1) were prepared as described in the protocol (Figure 2 ) and then aerobic packaging was done with low density polyethylene (150 $\mu \mathrm{m}$ thickness) for storage.

Formulas used in the estimation of the economics of product

Assuming that, $100 \mathrm{~kg}$ bhujia mix powder will be handled per day and working days/month is 25 days.

Cost of production for $100 \mathrm{Kg}$ formulation = Cost of formulation + cost of overhead production

Cost of overhead production $=$ Daily depreciation cost + Rent of building + Labour cost+ Cost of electricity + Maintenance cost + Water charge + Cost of packaging

Cost of $1 \mathrm{~kg}$ bhujia $=$

Production cost of $100 \mathrm{Kg}$ formulation

$100(1+\%$ Water absorption during dough preparation) $\mathrm{X} \%$ Cooking yield

Income $=$ Total sale price - Total cost of production

Break-Even point $=$ Fixed cost $\times$ Total sales $/$ (Total sales - Variable cost)

Cost-benefit ratio $=$ Total profit $/$ Total cost of production

Net profit/day $=$ Total profit - Amount of loan payment/day

\section{Results and Discussion}

The total cost of formulation for spice mix was calculated to be Rs. $313 / \mathrm{kg}$ is presented in Table 2. The total cost of production for chicken powder was calculated to be Rs. 929 (Table 3). The equipment cost required during this work is Rs. 45,000 (Table 4) and their annual depreciation was calculated to be Rs.
$4,500 /$ annum on the basis of $10 \%$ annual rate of depreciation (Table 5). The overhead production cost of $100 \mathrm{~kg}$ product was mentioned in Table 5 which includes daily depreciation cost, rent on building per day, labour cost, electricity cost, maintenance cost, water charge and packaging cost, thus, amounting to a total of Rs. 2,165/day.

The formulation cost for $100 \mathrm{~kg}$ bhujia mix powder were Rs. 15,430.00, Rs. 23,920.00, Rs. 28,165.00 and Rs. 32,410.00 in Treatment A, Treatment B, Treatment C and Treatment D respectively (Table-6). In every working day, $100 \mathrm{~kg}$ bhujia mix powders was processed and hence per day expenditure cost for processing of $100 \mathrm{~kg}$ bhujia mix powder was calculated as Rs. 17,595.00, Rs. 26,085.00, Rs. 30,330.00 and Rs. 34,575.00 in Treatment A, Treatment B, Treatment C and Treatment D respectively (Table 7).

Water absorption during dough preparation was measured as $43 \%, 49 \%, 52 \%$ and $55 \%$ in Treatment A, Treatment B, Treatment $\mathrm{C}$ and Treatment $\mathrm{D}$ respectively (Table 8 ). Yield of final product was found to be $84.04 \%$, $87.36 \%, 91.64 \%$ and $95.37 \%$ of weight of dough in Treatment A, Treatment B, Treatment $\mathrm{C}$ and Treatment $\mathrm{D}$ respectively (Table 8). Total sale/day was calculated to be Rs. 22,873.29, Rs. 33,910.85, Rs. 39,428.28 and Rs. 44,947.37 in Treatment A, Treatment $\mathrm{B}$, Treatment $\mathrm{C}$ and Treatment $\mathrm{D}$ respectively (Table 8). Daily profit was calculated to be Rs. 5,278.17, Rs. 7,825.58, Rs. 9,098.62 and Rs. 10,372.81 in Treatment A, Treatment B, Treatment $\mathrm{C}$ and Treatment $\mathrm{D}$ respectively (Table-8).

The total project cost was calculated by summation of the fixed cost and variable cost in Table 9 as Rs. 62,595.00, Rs. 71,085.00, Rs. 75,330.00 and Rs. 79,575.00 for Treatment A, Treatment B, Treatment $\mathrm{C}$ and Treatment D respectively (Table 9 ). 
Table.1 Formulation of bhujia (in percentage)

\begin{tabular}{|l|l|c|c|c|c|}
\hline S. No. & Ingredients & $\begin{array}{c}\text { Treatment } \\
\text { A }\end{array}$ & Treatment B & Treatment & Treatment D \\
\hline $\mathbf{1}$ & Gram flour & 60 & 50 & 45 & 40 \\
\hline $\mathbf{2}$ & Spent hen meat powder & 0 & 10 & 15 & 20 \\
\hline $\mathbf{3}$ & Potato starch powder & 20 & 20 & 20 & 20 \\
\hline $\mathbf{4}$ & Rice flour & 10 & 10 & 10 & 10 \\
\hline $\mathbf{5}$ & Red chili powder & 1 & 1 & 1 & 1 \\
\hline $\mathbf{6}$ & Black pepper powder & 1 & 1 & 1 & 1 \\
\hline $\mathbf{7}$ & Garlic powder & 1 & 1 & 1 & 1 \\
\hline $\mathbf{8}$ & Chat masala & 2 & 2 & 2 & 2 \\
\hline $\mathbf{9}$ & Cardamom powder & 0.25 & 0.25 & 0.25 & 0.25 \\
\hline $\mathbf{1 0}$ & Asafoetida (Hing) & 0.25 & 0.25 & 0.25 & 0.25 \\
\hline $\mathbf{1 1}$ & Salt & 2 & 2 & 2 & 2 \\
\hline $\mathbf{1 2}$ & Refined Oil & 2.5 & 2.5 & 2.5 & 2.5 \\
\hline & Total & 100 & 100 & 100 & 100 \\
\hline
\end{tabular}

Table.2 Cost of formulation of spice mix used in bhujia

\begin{tabular}{|c|l|c|c|c|}
\hline S.No. & Name of Ingredients & Quantity (gm) & $\begin{array}{c}\text { Rate per Kg } \\
\text { (Rs.) }\end{array}$ & $\begin{array}{c}\text { Approx. cost } \\
\text { (Rs.) }\end{array}$ \\
\hline $\mathbf{1}$ & Garlic Powder & 100 & 300 & 30 \\
\hline $\mathbf{2}$ & Red chili Powder & 100 & 150 & 15 \\
\hline $\mathbf{3}$ & Chat Mashala & 200 & 500 & 100 \\
\hline $\mathbf{4}$ & Cardamom Powder & 25 & 1,200 & 30 \\
\hline $\mathbf{5}$ & Black Papper powder & 100 & 800 & 80 \\
\hline $\mathbf{6}$ & Asafoetida (Hing) & 25 & 1,000 & 25 \\
\hline $\mathbf{7}$ & Salt & 200 & 15 & 3 \\
\hline $\mathbf{8}$ & Oil & 250 & 120 & 30 \\
\hline & $\quad$ Total & 1,000 & & 313 \\
\hline
\end{tabular}

Table.3 Cost of production for chicken powder

\begin{tabular}{|l|c|}
\hline \multicolumn{1}{|c|}{ Heads } & Cost \\
\hline Price of live spent hen (Rs.) & $80 / \mathrm{Kg}$ \\
\hline Dressing Percentage (\%) & 65 \\
\hline Cost of 1 kg dressed carcass (Rs.) & 80 X $100 / 65=123.08$ \\
\hline Average recovery of deboned meat (\%) & 56 \\
\hline Cost of 1 Kg deboned meat (Rs.) & $123.08 \times 100 / 56=219.79$ \\
\hline Cost of 100 Kg deboned meat (Rs.) & 21,979 \\
\hline Yield of meat powder (\%) & 23.66 \\
\hline Cost of meat powder (Rs.) & $21,979 / 23.66=929$ \\
\hline Total cost of 1 kg meat powder (Rs.) & 929 \\
\hline
\end{tabular}


Table.4 Fixed expenditure (Equipments) cost for bhujia

\begin{tabular}{|c|l|c|}
\hline S.No. & \multicolumn{1}{|c|}{ Equipments } & Cost $($ Rs. $)$ \\
\hline $\mathbf{1}$ & Manual meat mincer & 3000 \\
\hline $\mathbf{2}$ & Pressure cooker & 1500 \\
\hline $\mathbf{3}$ & Balance & 1500 \\
\hline $\mathbf{4}$ & Furniture and utensils & 4000 \\
\hline $\mathbf{5}$ & Grinder & 1500 \\
\hline $\mathbf{6}$ & Packaging machine & 2000 \\
\hline $\mathbf{7}$ & Dryer & 30000 \\
\hline $\mathbf{8}$ & Bhujia making machine & 1000 \\
\hline $\mathbf{9}$ & Miscellaneous & 500 \\
\hline & Total fixed expenditure & Rs. 45,000 \\
\hline
\end{tabular}

Table.5 Overhead production cost of $100 \mathrm{~kg}$ bhujia

\begin{tabular}{|c|c|c|}
\hline S.No. & Item & Cost \\
\hline 1 & $\begin{array}{l}\text { Annual depreciation } \\
\text { Daily depreciation cost }\end{array}$ & $\begin{array}{c}\text { @ } 10 \%=\text { Rs. } 4500 / \text { annum } \\
\text { @ 25 working day/month = Rs. 15/day }\end{array}$ \\
\hline 2 & $\begin{array}{l}\text { Rent of building } \\
\text { Rent per day }\end{array}$ & $\begin{array}{l}2000 / \text { month } \\
\text { @ } 25 \text { working day/month = Rs.80/day }\end{array}$ \\
\hline 3 & $\begin{array}{l}\text { Labour cost } \\
\text { Trained labour ( } 2 \text { nos.) } \\
\text { Untrained labour (1 nos.) }\end{array}$ & $\begin{array}{l}@ \text { Rs. } 300 X 2=\text { Rs. } 600 \\
@ \text { Rs. } 250 X 1=\text { Rs. } 250\end{array}$ \\
\hline 4 & Electricity cost & $\begin{array}{c}\text { @ Rs 6/unit } \\
\text { Approx. used 25 unit =Rs.150 }\end{array}$ \\
\hline 5 & Maintenance cost & Rs. 50 \\
\hline 6 & Water charge & Rs. 20 \\
\hline 7 & $\begin{array}{l}\text { Cost of packaging (1000 packet } \\
\text { @ Rs.1/packet) }\end{array}$ & Rs. 1000 \\
\hline & Total & Rs. 2165/day \\
\hline
\end{tabular}

Table.6 Formulation cost for $100 \mathrm{~kg}$ bhujia mix powder

\begin{tabular}{|c|l|c|c|c|c|c|}
\hline S.No. & \multicolumn{1}{|c|}{ Ingredients } & $\begin{array}{c}\text { Rate per Kg } \\
\text { (Rs.) }\end{array}$ & $\begin{array}{c}\text { A } \\
(\text { Rs. })\end{array}$ & $\begin{array}{c}\text { B } \\
(\text { Rs. })\end{array}$ & $\begin{array}{c}\text { C } \\
(\text { Rs. })\end{array}$ & $\begin{array}{c}\text { D } \\
(\text { Rs. })\end{array}$ \\
\hline $\mathbf{1}$ & $\begin{array}{l}\text { Gram flour @60\%, 50\%, 45\% \& } \\
\text { 40\% respectively }\end{array}$ & 100 & 6,000 & 5,000 & 4,500 & 4,000 \\
\hline $\mathbf{2}$ & Potato Starch @ 20\% & 40 & 800 & 800 & 800 & 800 \\
\hline $\mathbf{3}$ & Rice Flour @ 10\% & 50 & 500 & 500 & 500 & 500 \\
\hline $\mathbf{4}$ & $\begin{array}{l}\text { Chicken Powder @ 0\%, 10\%, } \\
\text { 15\% \& 20\% respectively }\end{array}$ & 949 & 0 & 9,490 & 14,235 & 18,980 \\
\hline $\mathbf{5}$ & Spice mix@ 10\% & 313 & 3,130 & 3,130 & 3,130 & 3,130 \\
\hline $\mathbf{6}$ & Frying oil (50 Kg) & 100 & 5,000 & 5,000 & 5,000 & 2,400 \\
\hline & \multicolumn{1}{|c}{ Total } & & 15,430 & 23,920 & 28,165 & 32,410 \\
\hline
\end{tabular}


Table.7 Total expenditure for $100 \mathrm{~kg}$ bhujia mix powder

\begin{tabular}{|c|l|c|c|c|c|}
\hline S.No. & \multicolumn{1}{|c|}{ Treatment } & A (Rs.) & B (Rs.) & C (Rs.) & D (Rs.) \\
\hline $\mathbf{1}$ & Daily depreciation cost & 15 & 15 & 15 & 15 \\
\hline $\mathbf{2}$ & Rent per day & 80 & 80 & 80 & 80 \\
\hline $\mathbf{3}$ & Labour cost & 850 & 850 & 850 & 850 \\
\hline $\mathbf{4}$ & Electricity cost & 150 & 150 & 150 & 150 \\
\hline $\mathbf{5}$ & Maintenance cost & 50 & 50 & 50 & 50 \\
\hline $\mathbf{6}$ & Water charge & 20 & 20 & 20 & 20 \\
\hline $\mathbf{7}$ & $\begin{array}{l}\text { Packaging cost (1000 packet @ } \\
\text { Rs.1/packet) }\end{array}$ & 1,000 & 1,000 & 1,000 & 1,000 \\
\hline $\mathbf{8}$ & $\begin{array}{l}\text { Total cost of 100 Kg bhujia mix } \\
\text { powder }\end{array}$ & 15,430 & 23,920 & 28,165 & 32,410 \\
\hline & $\quad$ Total & 17,595 & 26,085 & 30,330 & 34,575 \\
\hline
\end{tabular}

Table.8 Calculation of MRP, sale/day and total profit/day

\begin{tabular}{|l|c|c|c|c|}
\hline \multicolumn{1}{|c|}{ Treatment } & A & B & C & D \\
\hline $\begin{array}{l}\text { Water absorption during dough } \\
\text { preparation (\%) }\end{array}$ & 43 & 49 & 52 & 55 \\
\hline Yield (\%) & & & & \\
\hline Cost of production for 1 kg bhujia (Rs.) & 146.41 & 200.40 & 217.74 & 233.89 \\
\hline Profit @30\% & 43.92 & 60.12 & 65.32 & 70.17 \\
\hline MRP on the product (1 Kg) (Rs.) & 190.33 & 260.52 & 283.06 & 304.06 \\
\hline Income/Kg bhujia (Rs.) & 43.92 & 60.12 & 65.32 & 70.17 \\
\hline Daily production (Kg) & 120.177 & 130.166 & 139.293 & 147.824 \\
\hline Total sale money/day (Rs.) & $22,873.29$ & $33,910.85$ & $39,428.28$ & $44,947.37$ \\
\hline Total profit/day (Rs.) & $5,278.17$ & $7,825.58$ & $9,098.62$ & $10,372.81$ \\
\hline
\end{tabular}

Table.9 Calculation of variable cost, total project cost and net profit

\begin{tabular}{|l|c|c|c|c|}
\hline \multicolumn{1}{|c|}{ Treatment } & A (Rs.) & B (Rs.) & C (Rs.) & D (Rs.) \\
\hline Fixed cost & 45,000 & 45,000 & 45,000 & 45,000 \\
\hline Variable cost & 17,595 & 26,085 & 30,330 & 34,575 \\
\hline Total Project cost & 62,595 & 71,085 & 75,330 & 79,575 \\
\hline Loan amount (85\%) & 53,200 & 60,400 & 64,000 & 67,600 \\
\hline Margin money & 9,395 & 10,685 & 11,330 & 11,975 \\
\hline Amount of interest @ 12\% /annum & $7,511.4$ & $8,530.2$ & $9,039.6$ & 9549 \\
\hline Amount of loan payment/month & 625.95 & 710.85 & 753.3 & 795.75 \\
\hline Amount of loan payment/day & 25.038 & 28.434 & 30.132 & 31.83 \\
\hline Net profit/day & $5,253.14$ & $7,797.15$ & $9,068.49$ & $10,340.98$ \\
\hline
\end{tabular}


Table.10 Calculation of break-even point and cost benefit ratio

\begin{tabular}{|c|c|c|}
\hline Treatment & Break-even point & Cost benefit ratio \\
\hline $\mathbf{A}$ & $45000 \times 22873.29 /(22873.29-17595)$ & $\begin{array}{c}5278.174 / 17595=0.30 \\
\text { Or } 30 \%\end{array}$ \\
\hline $\mathbf{B}$ & $45000 \times 33910.85 /(33910.85-26085)$ & $\begin{array}{c}7825.58 / 26085=0.30 \\
\text { Or } 30 \%\end{array}$ \\
\hline $\mathbf{C}$ & $45000 \times 39428.28 /(39428.28-30330)$ & $\begin{array}{c}9098.619 / 30330=0.30 \\
\text { Or } 30 \%\end{array}$ \\
\hline $\mathbf{D}$ & $45000 \times 44947.37 /(44947.37-34575)$ & $10372.81 / 34575=0.30$ \\
& $=1,95,002$ & Or $30 \%$ \\
\hline
\end{tabular}

Fig.1: Flow chart for preparation of spent hen meat powder

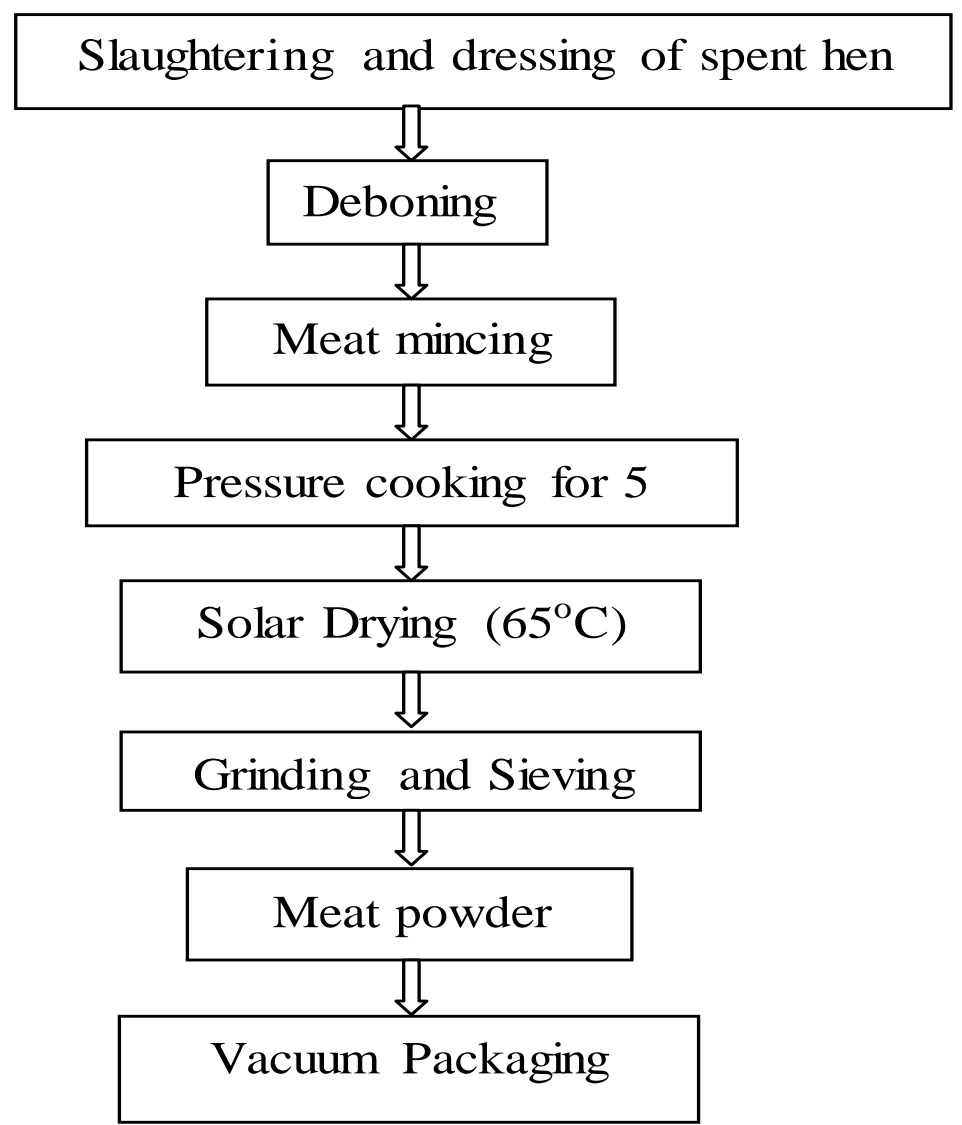


Fig.2 Flow chart for preparation of chicken bhujia

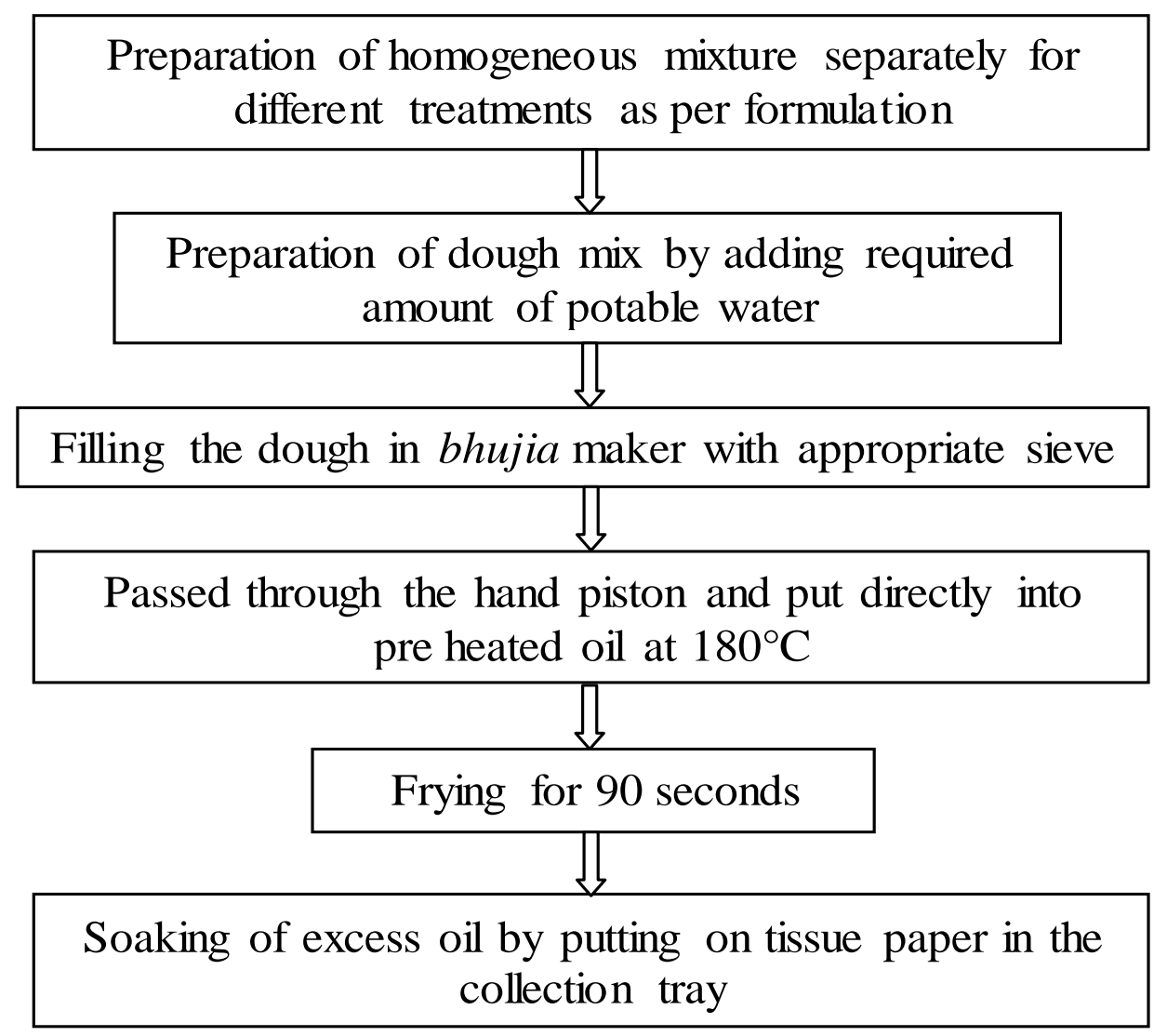

The break-even point was calculated to be Rs. 1,95,006.00, Rs. 1,94,993.00, Rs. 1,95,012.00 and Rs. 1,95,002.00 for Treatment A, Treatment B, Treatment C and Treatment D respectively (Table 10). Cost benefit ratio was found to be $30 \%$ for all four treatments.

Thus, viable enterprises can be established in tropical countries such as India by keeping MRP (Maximum Retail Price) of bhujia as Rs. 190, Rs. 261, Rs. 283 and Rs. 304 per kg for Treatment A, Treatment B, Treatment C and Treatment D respectively (Table 8 ).

From the above study, it can be suggested that development and adaptation of the technology by the small and medium scale entrepreneurs will be a profitable one which will pave their way into the meat processing business by utilization of undesirable old and culled hens.
Moreover, it will provide impetus to the food processing industry besides making healthy and nutrient enriched meat products available to the consumers and hence creating ample opportunity for employment generation.

\section{References}

BAHS (2014). Basic animal husbandry and fisheries statistics, Government of India, Ministry of Agriculture and Farmers Welfare, Department of Animal Husbandry.

Bowser, T. J., Mwavita, M., Al-Sakini, A., McGlynn, W. and Maness, N.O. (2014). Quality and Shelf Life of Fermented Lamb Meat Sausage with Rosemary Extract. Food Science Journal. 8:22-31.

DAHD \& F. (2012). Annual report. 
Department of Animal Husbandry, Dairying and Fisheries. Ministry of Agriculture, Government of India.

Desikan, T. and Megarajan, B. (2014). Prospects of value-added poultry products marketing in India. Animal and Veterinary Sciences. 2(4): 118-123.

Kondaiah, N. and Panda, B. (1992). Processing and utilization of spent hens. World Poult. Sci. 48: 255-268.

Kotaiah, T. (2018). Poultry Production in India - The Current Scenario. FnBnews.com

Kumar, Y., Singh, P., Tanwar, V.K., Ponnusamy, P., Singh, P.K. and Shukla,
P. (2015). Augmentation of quality attributes of chicken tikka prepared from spent hen meat with lemon juice and ginger extract marination. Nutrition \& Food Science. 45(4): 606-615.

Saini, A., Pandey, A., Sharma, S., Meena, P., Gurjar A.S. and Raman. R. (2018). Development and Cost Economics of Chicken Powder Incorporated Shelf Stable Fried Snack Prepared from Spent Hen Meat with Rosemary and Betel Leaves Extract. Int.J.Curr.Microbiol. App.Sci. 7(02): 1719-1726.

\section{How to cite this article:}

Sarkar, B.K., S. Upadhyay, P. Gogoi, A. Das and Hazarika, M. 2019. Development and Cost Economics of Bhujia Incorporated with Spent Hen Meat Powder. Int.J.Curr.Microbiol.App.Sci. 8(02): 1158-1166. doi: https://doi.org/10.20546/ijcmas.2019.802.135b 